\title{
Sociodemographic Determinants and Common Reasons for Visiting the Emergency Dental Service in the City of Zagreb
}

\section{Socijalno-demografske odrednice i česti razlozi za posjet hitnoj stomatološkoj službi Grada Zagreba}

Community healthcare center „Zagreb - Centar“, Runjainova 4, Zagreb, Croatia

Dom zdravlja Zagreb - Centar, Runjaninova 4, Zagreb, Hrvatska

\section{Abstract}

Objective: The objective of the study was to determine the sociodemographic and clinical parameters of patients who visit the emergency dental service and their most common diagnoses. Materials and Methods: The data were collected on the basis of a survey filled out by patients. A total of 1730 out of 6732 patients (26\%) were surveyed using a questionnaire to analyze sociodemographic status, dental visits, the description and dynamics of the symptoms. After the data collection, methods of descriptive data presentation and of inferential statistics were made in SPSS. Results: Survey results show that most subjects $(60.4 \%)$ came during the weekends and holidays. The subjects, 73.1 $\%$ of them, stated that they had already used this type of service, and $65.8 \%$ did not visit their dentist beforehand. The largest number of subjects (62.2\%) reported that they needed emergency service within a week after their problems had begun. The most common diagnoses included face and jaw abscesses (27.3\%). There is a statistically significant difference between the number of patients who went to the emergency dental service and completed the questionnaire over the course of several months contrary to patients who were there in May and June (59.7\%) compared to July and August $(40.3 \%)$. Conclusions: Most subjects had clear indications for being referred to an emergency dental service. Most of the emergency conditions were mainly due to irregular visits to the dentist. Patient education and preventive programs would probably have reduced the number of visits.
Received: February 26, 2019

Accepted: July 25, 2019

Address for correspondence Alem Fazlic, DMD

Community healthcare center

„Zagreb - Centar“

Runjaninova 4, 10000 Zagreb, Croatia alem.fazlic@gmail.com

Key words

Dental Anxiety; Acute Pain; Emergency Medicine

\section{Introduction}

The emergency dental service in the City of Zagreb has been working continuously for almost 15 years and during this period it has been possible to provide dental care to patients with acute dental conditions at night, weekends and holidays. The service is organized in three locations: Runjaninova 4 (Headquarters of the Health Center Zagreb - Centre), Clinical Hospital Dubrava and the Avenue of Većeslav Holjevac 22. Locations are situated in the central, eastern and southern part of the city to facilitate access to patients from different parts of the city (1). Dental care is provided to patients on working days from 10 PM to 06 AM, on Saturdays from $3 \mathrm{PM}$ to $8 \mathrm{PM}$ and from $10 \mathrm{PM}$ until Monday to 06 $\mathrm{AM}$ and on public holidays 24/7. The funding comes from the City of Zagreb and the Croatian Institute for Health Insurance. Examinations, procedures and the prescriptions are free of charge for the Croatian Institute for Health Insurance insured persons. This type of service is unique in comparison to other EU countries where such a service does not exist $(2,3)$ or is limited to emergency hospital admissions $(4,5)$. The goal of this study was to determine the sociodemographic and clinical parameters of patients who visit the emergency dental service and their most common diagnoses.
Uvod

Hitna stomatološka služba Grada Zagreba kontinuirano radi gotovo 15 godina i u tom je razdoblju omogućena dostupnost stomatološkoj skrbi pacijentima s akutnim stomatološkim stanjima tijekom noći te vikendima i blagdanima. Služba je organizirana na trima lokacijama - u Runjaninovoj 4 (sjedište Doma zdravlja Zagreb - Centar), u Kliničkoj bolnici Dubrava i u Aveniji Većeslava Holjevca 22. Dakle, nalazi se u srednjem, istočnom i južnom dijelu Zagreba kako bi se olakšala dostupnost pacijentima iz različitih dijelova grada (1). Stomatološka zaštita osigurana je pacijentima radnim danima od 22 do 6 sati, subotom od 15 do 20 sati i ponovno od 22 sata pa sve do ponedjeljka do 6 sati te blagdanima od 0 do 24 sata. Financiraju je Grad Zagreb i Hrvatski zavod za zdravstveno osiguranje. Pregledi, zahvati i izdavanje recepata besplatni su za osiguranike HZZO-a. Takav oblik službe jedinstven je u usporedbi $s$ drugim zemljama EU-a, gdje takva služba ne postoji $(2,3)$ ili je ograničena na bolnice s hitnim prijmom $(4,5)$. Svrha ovoga rada bila je ustanoviti socijalno-demografske i kliničke parametre pacijenata koji posjećuju hitnu stomatološku službu te njihove najčešće dijagnoze. 


\section{Material and methods}

Sample

The study was conducted by the Community healthcare Centre "Zagreb - Centar" at three locations of the emergency dental service (Runjaninova 4, Clinical Hospital Dubrava and the Avenue of Većeslav Holjevac 22) during 4 months (from 1 May to 31 August 2015). During this period, emergency services were visited by 6732 patients - 2384 at Runjaninova 4, 2511 at Clinical Hospital Dubrava and 1837 at the Avenue of Većeslav Holjevac 22 locations. All participating patients were informed about the study, and all of them signed the informed consent. The study received the institutional ethical board approval. The survey included $1730 \mathrm{pa}-$ tients who voluntarily filled out the questionnaire with provided anonymity in answering, which is $26 \%$ of the total number of patients. The purpose of the survey and how to properly fill out the questionnaire was described to all participants, assistance in completing the questionnaire was given and in each filled out survey, it was verified that all the questions were answered in the correct manner.

\section{Selection Criteria}

This is a random sample of patients who were given a survey before the admission to the emergency room of dental care.

\section{Questionnaire}

The questionnaire consisted of two parts. It was written in Croatian on two sides of a sheet of paper (Figure 1, Figure 2). The patient was asked to circle one of the offered answers, write with letters or numbers the answers that were not for circling, mark the drawing of a part that troubled him/her, and on a numeric scale of 0-10 mark the number that is related to the intensity of the patient's pain. The first part was filled by a patient, and another by the dental practitioner. The patient's part questions were: the patient's socio-demographic data (age, gender, marital status, work status, place of residence), information about visiting his chosen dentist and data on the current condition and the reason for the patient's arrival to the emergency dental service. These include questions about the start date and the level of pain according to his/her own assessment of when it started and the current status, about the pain localization, the subjective description of the pain and the dynamics of pain. The second part was filled out by the dental practitioner and it contained the date, time of arrival and diagnosis (Figures 1,2).

\section{Statistical analysis}

The results of the survey were processed by a statistical program SPSS for Windows personal computer, version 20.0. In accordance with the basic descriptive statistics, methods of descriptive data presentation and of inferential statistics were used. To test the difference between the groups, the chi-squared test was used.

\section{Results}

At all three locations in which emergency dental service is provided, there was an average of 17630 patients per year

\section{Ispitanici i metode}

\section{Uzorak}

Istraživanje je proveo Dom zdravlja Zagreb - Centar na trima lokacijama hitne stomatološke službe (Runjaninova 4, Klinička bolnica Dubrava i Avenija Većeslava Holjevca 22) tijekom četiri mjeseca (od 1. svibnja do 31. kolovoza 2015.). U tom razdoblju hitnu službu posjetila su 6732 pacijenta 2384 na lokaciji u Runjaninovoj 4, 2511 na lokaciji KB Dubrava te 1837 na lokaciji u Aveniji Većeslava Holjevca 22. Svi pacijenti koji su ispunili upitnik bili su obaviješteni o tome što se traži, te su potpisali informirani pristanak. Studija je dobila odobrenje institucionalnog etičkog odbora. U istraživanje je bilo uključeno 1730 pacijenata koji su dobrovoljno ispunili upitnik i kojima je osigurana anonimnost pri odgovaranju, što je $26 \%$ od ukupnog broja pacijenata. Svim sudionicima opisana je svrha istraživanja te način na koji će ispravno ispuniti upitnik, a pritom im je pružena pomoć $u$ ispunjavanju. Naposljetku, svaki je ispunjeni upitnik provjeren kako bi se ustanovilo je li na sva pitanja pravilno odgovoreno.

\section{Kriterij odabira}

Riječ je o prigodnom uzorku pacijenata kojima je anketa dana pri ulasku u hitni prijam stomatološke zaštite.

\section{Upitnik}

Upitnik se sastojao od dvaju dijelova. Napisan je na hrvatskome jeziku te se nalazio na obje strane jednoga lista papira (slika 1., slika 2.). Od pacijenta se tražilo da zaokruži jedan od ponuđenih odgovora, upiše slovima ili brojkama odgovore koji se nisu zaokruživali, označi na crtežu dio koji ga boli te na numeričkoj ljestvici od 0 do 10 označi broj koji se odnosi na jačinu njegove boli. Prvi dio ispunjavao je pacijent, a drugi doktor dentalne medicine. Dio koji je ispunjavao pacijent odnosi se na socijalo-demografske podatke (dob, spol, bračni status, radni status, mjesto stanovanja), podatke o posjećivanju izabranog stomatologa i one o trenutačnom stanju zbog kojega se pacijent javio u hitnu stomatološku službu. To uključuje pitanja o datumu početka tegoba i razini boli prema vlastitoj procjeni (kad je bol počela i kakva je trenutačno), o lokalizaciji boli, o subjektivnom opisu boli te o njezinoj dinamici. Drugi dio, koji ispunjava doktor dentalne medicine, sadržava podatke o datumu i vremenu dolaska te o samoj dijagnozi (Slika 1., Slika 2.).

\section{Statistička analiza}

Rezultati provedenog istraživanja obrađeni su statističkim Windowsovim programom SPSS za osobna računala, verzija 20,0 . U skladu s osnovnom deskriptivnom statistikom korištene su metode deskriptivnog prikaza podataka te metode inferencijalne statistike. Za testiranje razlika između skupina primijenjen je hi-kvadrat test.

\section{Rezultati}

$\mathrm{Na}$ sva tri mjesta na kojima se pruža hitna stomatološka usluga prosječno je, u razdoblju od 2011. do 2015., zatražilo 
in the period from 2011 to 2015, and the number of patients each year increased by an average of $2.9 \%$. The total increase in patient numbers from 2011 to 2015 is $11.9 \%$. In 2015, a total of 44,222 procedures were performed on 18,519 patients who visited our service. The majority of subjects came on weekends and holidays (60.4\%), $52.9 \%$ of subjects were male and $47.1 \%$ female. The age of subjects ranged between 1 and 97, with an average age of 37. Figure 3 shows the age of subjects, divided into groups in the span of five years. The most frequent subjects were younger adults, the most represented age groups were $21-25(15,3 \%), 26-30(13,3 \%)$ and $31-35$ years of age $(11,5 \%)$. These age groups were statistically more prevalent $(\mathrm{p}<0,05)$ compared to the other age groups (Figure 3.). According to marital status, $48.1 \%$ of subjects were unmarried, $44.2 \%$ of subjects were married, and $5.8 \%$ of subjects divorced and $1.9 \%$ of respondents were widowers / widows. According to the working status, most subjects were employed (53.4\%), while students were in the minority $(8.8 \%)$. There were equal numbers of students and retired $(10.6 \%)$, while there was a slightly larger number of unemployed (16.5\%). 96.6\% of patients who were referred to the emergency dental service were registered in the Croatian Institute for Health Insurance, while only 3.4\% were not and most patients came from the City of Zagreb (79.1\%), $11.7 \%$ from the Zagreb County, 9, 1\% from other parts of the country where dental care outside the normal working hours is not provided.

Only $26.8 \%$ of patients have never been to the emergency dental service, i.e. it was their first visit and $15.9 \%$ of them visited the emergency dental service twice before the actual visit, $8.3 \%$ had been there three times, while $10.8 \%$ had visited the service more than three times. Only 34.3\% of subjects visited their dentist because of the problem, while $65.7 \%$ did not. On average, 7 days had elapsed since a visit to their dentist due to an existing problem before the subjects went to the emergency dental service. The largest number of subjects $(62.2 \%)$ was referred to the emergency dental service within a week after the problems began. Patients who were referred to the emergency dental service had to evaluate the strength of their pain on a scale from 1 to 10 , the average being 8 . Subjects rated the highest pain by the discomfort they reported to the emergency dental service on rankings from 1 to 10 by 7 ; the highest number of subjects (18.7\%) rated their most severe pain with 8 . Patients, $69,8 \%$ of them were taking medication because of the current problems they reported to emergency service, while $30.2 \%$ of patients did not take medication. Out of $69.8 \%$ of the patients taking the medication, $60.4 \%$ of them stated that they were taking analgesics, and $9.4 \%$ of patients had taken antibiotics.

The patients who were not registered in the Croatian Institute for Health Insurance were at the average age of 31, $53.4 \%$ males and $46.6 \%$ females, mostly unmarried $(63.8 \%)$. According to the working status, $40 \%$ were employed, $36.4 \%$ were unemployed, $10.9 \%$ were retired, $9.1 \%$ were pupils and $3.6 \%$ were students. The subjects in the amount of $75.9 \%$ who were not registered in the Croatian Institute for Health Insurance and were residents of the City of Zagreb and 6.9\% of them lived in Zagreb County. For $25.9 \%$ of those who pomoć 7630 pacijenata na godinu i njihov se broj svake godine povećavao u prosjeku za 2,9\%. Tako ukupni porast broja pacijenata od 2011. do 2015. iznosi $11,9 \%$. U 2015. godini obavljena su ukupno 44222 zahvata na 18519 pacijenata koji su posjetili hitnu službu. Većina ispitanika dolazila je vikendom i praznicima $(60,4 \%)$. Među njima je muškaraca bilo $52,9 \%$, a žena 47,1\%. Dob ispitanika kretala se između 1 i 97 godina, pri čemu je prosjek bio 37 godina. Na Slici 3. prikazana je dob ispitanika raspoređena u skupine u rasponu od pet godina. Najčešće su dolazili ispitanici mlađe odrasle dobi - najzastupljenije dobne skupine bile su osobe od 21 do 25 godina (15,3\%), od 26 do $30(13,3 \%)$ te od 31 do $35(11,5$ $\%)$. Te dobne skupine statistički su prevladavale $(\mathrm{p}<0,05) \mathrm{u}$ odnosu prema ostalim dobnim skupinama (Slika 3.). Prema bračnom statusu, iz ankete je vidljivo da je 48,1\% ispitanika neoženjeno/neudano, 44,2 \% ispitanika je oženjeno/udano, 5,8 \% ispitanika je razvedeno, a 1,9 \% su udovci/udovice. Prema radnom statusu najviše je ispitanika zaposleno (53,4 $\%)$, a najmanje je učenika $(8,8 \%)$. Podjednak je bio broj studenata i umirovljenika $(10,6 \%)$, a nešto više bilo je nezaposlenih (16,5\%). Istaknimo da je 96,6\% pacijenata koji dolaze u hitnu stomatološku službu prijavljeno preko HZZO-a, a samo 3,4 \% nije prijavljeno. Većina pacijenata bila je iz Grada Zagreba (79,1\%), 11,7 \% iz Zagrebačke županije, a 9,1\% iz drugih dijelova Hrvatske u kojima nije osigurana stomatološka zaštita izvan uobičajenog radnog vremena.

Samo 26,8 \% ispitanika nikad nije posjetilo hitnu stomatološku službu, odnosno to im je prvi posjet. Njih 15,9 \% dva je puta bilo u hitnoj službi prije aktualnog posjeta, 8,3 \% tri puta, a njih 10,8 \% došlo je više od tri puta. Samo 34,3 $\%$ ispitanika posjetilo je svojeg stomatologa zbog aktualnog problema, a njih $65,7 \%$ nije. U prosjeku je proteklo sedam dana od posjeta svojem stomatologu zbog postojećeg problema, prije nego što su se ispitanici javili hitnoj službi. Najveći broj ispitanika $(62,2 \%)$ hitnoj se službi obratio unutar tjedan dana od početka tegoba. Pacijenti koji dolaze u hitnu stomatološku službu jačinu svoje boli, na ljestvici od 1 do 10 , u prosjeku ocjenjuju s 8 . Ispitanici su u prosjeku najjaču bol izazvanu tegobama zbog kojih su došli u hitnu stomatološku službu na ljestvici od 1 do 10 ocjenjivali brojem 7, a najviše njih $(18,7 \%)$ svoju najjaču bol ocijenio je s 8 . Pritom je 69,8\% pacijenata uzimalo lijekove zbog aktualnih problema zbog kojih su se javili hitnoj službi, a 30,2\% nije uzimalo lijekove. Od 69,8 \% ispitanika koji su uzimali lijekove, 60,4 $\%$ odgovorilo je da su se odlučili za analgetike, a 9,4\% popilo je antibiotike.

Pacijenti koji nisu prijavljeni preko HZZO-a prosječne su dobi od 31 godine - od njih su 53,4 \% muškarci, a 46,6 \% žene, većinom neoženjeni/neudane $(63,8 \%)$. Prema radnom statusu zaposleno je njih $40 \%$, a 36,4 \% je nezaposleno, 10,9 $\%$ je umirovljenika, 9,1 \% učenika i 3,6 \% studenata. U Zagrebu živi 75,9\% ispitanika koji nisu prijavljeni preko HZZO-a, a 6,9 \% u Zagrebačkoj županiji. Za 25,9 \% ispitanika koji nisu prijavljeni preko HZZO-a to je prvi posjet hitnoj stomatološkoj službi, za 34,5\% drugi, a za 12,1 \% treći. Za njih $13,8 \%$ to je četvrti posjet, odnosno već su bili tri puta u hitnoj službi, a 13,8 \% ispitanika više je od tri puta zatražilo hitnu stomatološku pomoć. 
1
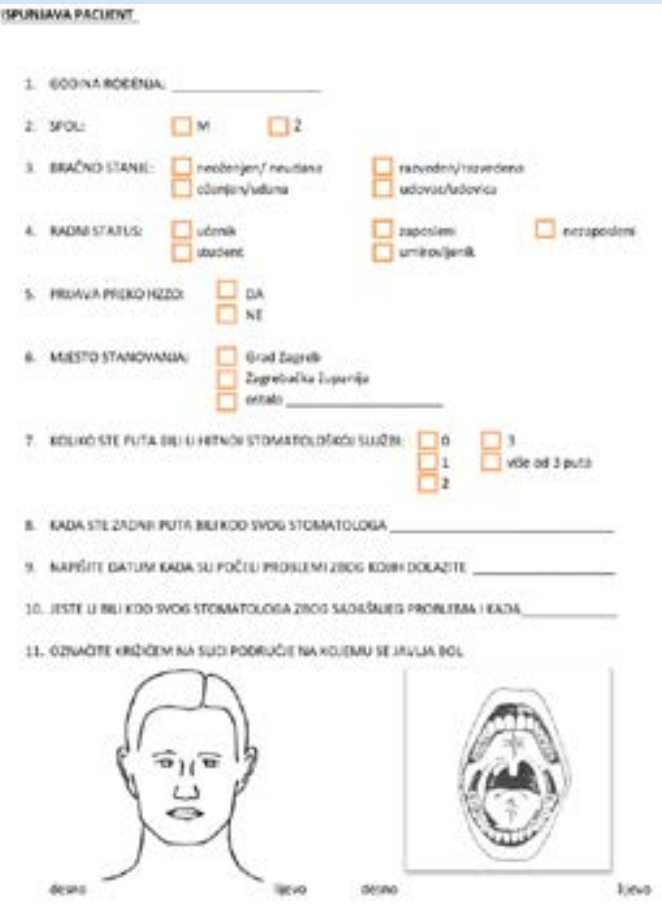

English translation :

Filled out by the patient

1. DATE OF BIRTH

2. GENDER

3. MARITAL STATUS: single/married/divorced/widower/widowed

4. EMPLOYMENT STATUS: student/employed/unemployed/retired

5. REGISTERED IN THE CROATIAN INSTITUTE FOR HEALTH INSURANCE

6. PLACE OF RESIDENCE: The City of Zagreb/Zagreb County/Other

7. HOW MANY TIMES HAVE YOU VISITED THE EMERGENCY DENTAL SERVICE - more than 3 times

8. WHEN WAS YOUR LAST VISIT TO THE DENTIST

9. WRITE DOWN THE DATE WHEN THE PROBLEMS BEGAN

10. HAVE YOU VISITED YOUR DENTIST REGARDING YOUR CURRENT SITUATION AND WHEN

11. MARK WITH AN "X" THE PLACE WHERE THE PAIN OCCURS LEFT/RIGHT

The data collected in the emergency dental service questionnaire are anonymous and will not be used for other purposes

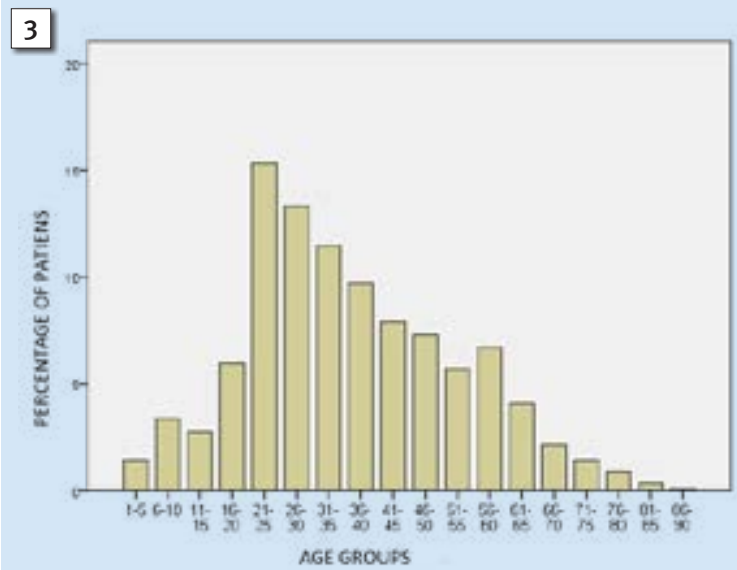

2
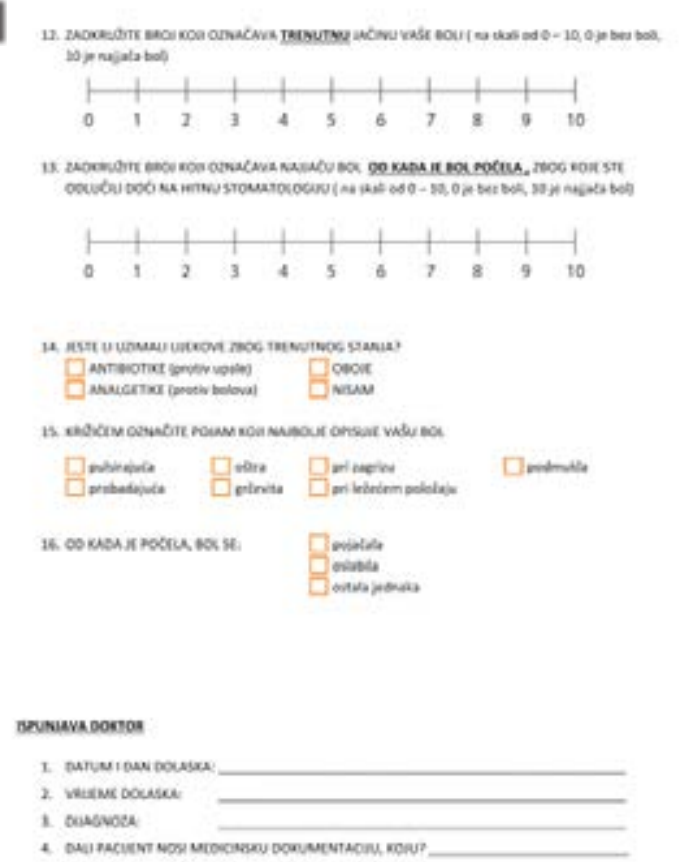

Circle the number that indicates your current pain intensity (on the scale of $0-10$, with 0 being no pain, 10 being the worst pain

Circle the number that indicates the worst pain from the moment it started that made you go to the emergency dental service ( $($ on the scale of $0-10$, with 0 being no pain, 10 being the worst pain)

14. HAVE YOU TAKEN ANY MEDICATION REGARDING YOUR CURRENT

SITUATION? Antibiotics (anti-inflammatory)/ analgesics (painkillers) /Both/ None of the above

15. Mark with an " $\mathrm{x}$ " the term that best describes your pain

Pulsating/stabbing/searing/spasmodic/while biting/ in the lying position/sly

16. Pain from the moment it started has: intensified/weakened/stayed the same

Filled out by the doctor

1. DATE AND DAY OF ARRIVAL

2. TIME OF ARRIVAL

3. DIAGNOSIS

4. DOES THE PATIENT CARRY MEDICAL DOCUMENTATION, IF YES, WHICH?

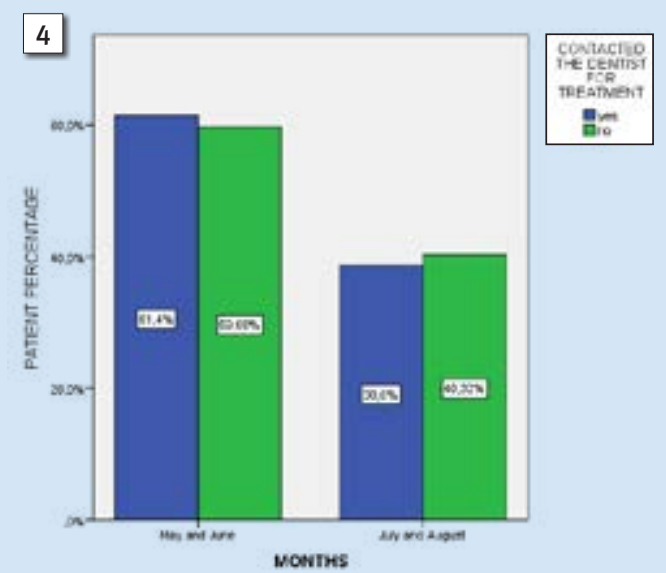

Figure 1 First page of the questionnaire handed out to patients who participated in our study

Slika 1. Prva stranica upitnika na jednom listu papira dana pacijentima koji su sudjelovali u našoj studiji

Figure 2 Second page of the questionnaire handed out to patients who participated in our study

Slika 2. Druga stranica upitnika na jednom listu papira dana pacijentima koji su sudjelovali u našoj studiji

Figure 3 Graphical presentation showing the distribution of different age groups of patients who filled out the survey

Slika 3. Grafički prikaz pokazuje distribuciju različitih dobnih skupina pacijenata koji su popunili upitnik

Figure 4 Graphical presentation of the chi squared test showing proportions of respondents who filled out the survey during May and June , July and August with regard to their prior visit to the dentist.

Slika 4. Grafički prikaz hi-kvadrat testa pokazuje razmjer ispitanika koji su anketu ispunili tijekom svibnja i lipnja te srpnja i kolovoza, s obzirom na prijašnji posjet stomatologu 


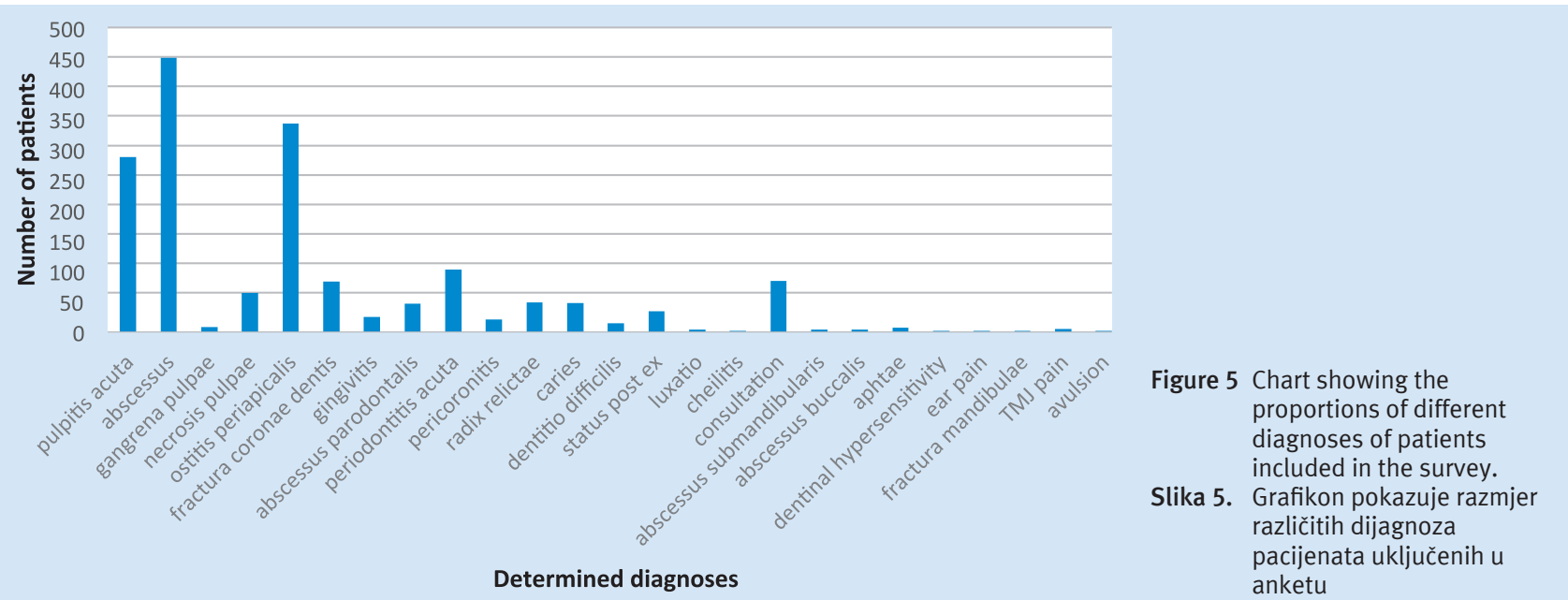

were not registered in the Croatian Institute for Health Insurance this was their first visit to the emergency dental service. For $34.5 \%$ of them, this was their second visit, for $12.1 \%$ the third. For $13.8 \%$ of them this was the fourth visit, i.e. they had previously been 3 times in the emergency dental service, while $13.8 \%$ of subjects visited the emergency dental service more than 3 times.

The pain was described as pulsating (43.5\%), sharp (17\%), while biting $(15.9 \%)$, sly $(13.4 \%)$, searing $(7.3 \%)$, spasmodic (1.6\%), in the lying position (1.3\%), and according to the dynamics, it was described as intensifying (58.6\%), unchanged $(30 \%)$ and weakened $(11.4 \%)$. The pain that made the patients go and ask for help at the emergency dental service was equally represented in all quadrants, in the 1 st quadrant $23.3 \%$, in the 2 nd quadrant $23.7 \%$, in the 3 rd quadrant $26.3 \%$ and in the fourth quadrant $23.3 \%$. Most subjects had visited the emergency dental service prior to the actual visit (38.2\%). The largest number of patients went to the emergency dental service during June (31.5\%) and during May (27.4\%) assuming the reason for this was a variety of bank holidays, vacations and little to none accessibility to a dental service during this period. Comparing these data to data collected through filling out the questionnaire during July and August we wanted to examine if there was a statistically significant difference in the number of reported patients during May and June; therefore, we used the chi-squared test. The results of the chi-squared test show that there is a statistically significant difference between the number of patients who completed the questionnaire during a visit to the emergency service during the various months $(\mathrm{p}<0.01)$, in the sense that more patients filled out the questionnaire during May and June (59.7\%), as compared to July and August $(40.3 \%)$. In order to ascertain whether there is a statistically significant difference between patients experiencing an emergency in May and June, relative to July and August, depending on whether the patients had previously contacted their dentist for the actual problem, and due to the fact that it is more difficult to schedule an appointment with a dentist when it is holiday season, we also used the chi-squared test. The results of the chi-squared test show that there is no statistically significant difference in the number of patients who
Bol je opisana kao pulsirajuća (43,5 \%), oštra (17 \%), pri zagrizu $(15,9 \%)$, podmukla $(13,4 \%)$, probadajuća $(7,3$ $\%)$, grčevita $(1,6 \%)$ i u ležećem položaju $(1,3 \%)$, a prema dinamici opisana je kao pojačavajuća $(58,6 \%)$, nepromijenjena $(30 \%)$ i oslabljena $(11,4 \%)$. Bol zbog koje se pacijenti javljaju u hitnu stomatološku službu podjednako je zastupljena u svim kvadrantima - u 1. kvadrantu 23,3 \%, u 2. kvadrantu $23,7 \%$, u 3 . kvadrantu $26,3 \%$ te u 4 . kvadrantu 23,3\%. Najveći broj ispitanika prije aktualnog posjeta jedanput je posjetio hitnu stomatološku službu (38,2 \%). Najveći broj pacijenata u hitnu se stomatološku službu javio tijekom lipnja $(31,5 \%)$ te u svibnju $(27,4 \%)$, pa se pretpostavlja da su razlog za to bili različiti državni praznici, godišnji odmori i gotovo nikakva dostupnost stomatološke službe u tom razdoblju. Usporedbom tih podataka s podatcima prikupljenima popunjavanjem upitnika tijekom srpnja i kolovoza, željeli smo ispitati postoji li statistički značajna razlika u broju pacijenata koji su došli u svibnju i lipnju - stoga smo se koristili hi-kvadrat testom. Rezultati pokazuju da postoji statistički značajna razlika između broja pacijenata koji su ispunili upitnik za posjeta hitnoj službi tijekom različitih mjeseci ( $\mathrm{p}<$ $0,01)$, jer je više njih ispunilo upitnik u svibnju i lipnju $(59,7$ $\%)$ u odnosu prema srpnju i kolovozu (40,3\%). Kako bismo provjerili postoji li statistički značajna razlika između pacijenata koji su se javljali u hitnu službu tijekom svibnja i lipnja u odnosu prema srpnju i kolovozu, ovisno o tomu jesu li se prije toga javili svojem stomatologu zbog aktualnog problema i zbog činjenice da je teže dogovoriti pregled kod stomatologa u sezoni godišnjih odmora, također smo izračunali hi-kvadrat test. Rezultati pokazuju da nema statistički značajne razlike u broju pacijenata koji su ispunili upitnik tijekom posjeta hitnoj stomatološkoj službi u svibnju i lipnju, odnosno srpnju i kolovozu, ovisno o tome jesu li se javili svojem stomatologu zbog aktualnog problema ( $\mathrm{p}>0,05)$. Pacijenti su se podjednako često javljali, odnosno nisu se javljali svojem stomatologu u svibnju i lipnju, kao i u srpnju i kolovozu (Slika 4.).

Najčešće dijagnoze bile su abscessus (uključuje sve apscese lica i čeljusti) - $27,3 \%$, ostitis periapicalis - 20,4\% te pulpitis acuta-17,2\%. (Slika 5.). 
completed the questionnaire during a visit to the dental service during May and June or July and August, depending on whether the patients had reported to their dentist about the actual problem ( $p>0.05$ ). The patients were equally and frequently visiting, or not visiting their dentists in May and June as well as in July and August (Figure 4).

The most common diagnoses were: abscessus (including all abscesses of the face and jaw) - 27.3\%, ostitis periapicalis 20.4\%, pulpitis acuta - 17.2\% (Figure 5).

\section{Discussion}

In this study, we have presented the sociodemographic structure of patients who visit our service and their main reasons of reporting in terms of the symptoms they are experiencing. In a survey that lasted from May 1 to August 31,2015 , the sample included 1730 patients surveyed at all emergency locations in the city of Zagreb. Of those surveyed $26.9 \%$ of them used emergency dental services for the first time, while $73.1 \%$ used it more often. We can conclude that the surveyed patients do not have the habit of going to their dental practitioner regularly, but are asking for help when the state of dental urgency arises. Also, $65.8 \%$ of subjects did not visit their dentist because of the current state, which confirms the fact that emergency dental services are often the first place for patients to report with an emergency according to their own perception. With regard to the most common diagnoses with which the patients report, it is evident that emergency dental services are being visited by patients with conditions that could be prevented at the dental practice of primary health care. In an emergency dental service survey in São Paulo, Brazil, it was reported that $80.4 \%$ of patients visited the service directly, without visiting a dentist in primary health care (6). In a survey conducted in Quebec, Canada, there is an increase in the number of children under 10 who have been admitted to their emergency dental service, despite the free dental care provided by local self-government, and as reasons for the lack of attendance, poor oral health awareness of the parents has been reported, long waiting for an appointment in private clinics, and parent's perception that the dentist does not have enough patience to work with the child (7).

Similar studies in other emergency dental services show that the causes of emergencies are similar to those of our research. The 1998 survey at the Department of Maxillofacial and Oral Surgery of the Clinical Hospital Dubrava showed in an analysis of emergency situations that the largest number of patients came on Saturdays and Sundays, mostly from the age group from 16 to 31, and the most common diagnoses were odontogenic inflammations (33.94\%) and soft tissue injuries (22.54\%). Of the total of 2766 patients, 130 (4.7\%) were hospitalized (8). Other studies report about irregular attendance and according to one study the average time the patient had been suffering from pain was 2 weeks, and in our study it was a week. Only $46 \%$ of patients had their own dentist and in our research $96.6 \%$ stated that they were registered in the Croatian Institute for Health Insurance which provides free dental care to all insured persons (9). The reason for irregular attendance may be the existence of dental anxiety. Some stud-

\section{Rasprava}

U ovom istraživanju prikazali smo socijalno-demografsku strukturu pacijenata koji posjećuju našu službu i glavne razloge njihova dolaska, dakle, simptome zbog kojih dolaze. $U$ anketi koja je trajala od 1. svibnja do 31. kolovoza 2015. godine imali smo uzorak od 1730 pacijenata ispitanih na svim lokacijama hitne službe u gradu Zagrebu. Od ispitanih pacijenata, njih $26,9 \%$ prvi se put koristilo uslugama hitne stomatologije, a 73,1 \% to je učinilo više puta. Možemo zaključiti da ispitani pacijenti nemaju naviku redovitog odlaska svojem doktoru dentalne medicine, nego dolaze po pomoć kada se stvori stanje hitnosti. Također, $65,8 \%$ ispitanika nije posjetilo svojeg stomatologa zbog trenutačnog stanja, što potvrđuje da je hitna stomatološka služba često prvo mjesto na koje pacijenti odlaze kada se prema njihovoj percepciji pojavi stanje hitnosti. S obzirom na najččšce dijagnoze, jasno je da hitnu stomatološku službu posjećuju pacijenti sa stanjima koja su se mogla prevenirati u stomatološkim ordinacijama primarne zdravstvene zaštite. $U$ istraživanju provedenom u sklopu hitne stomatološke službe u São Paulu u Brazilu, naveden je podatak da je 80,4\% pacijenata posjetilo službu direktno, bez odlaska stomatologu u primarnoj zdravstvenoj zaštiti (6). $\mathrm{U}$ istraživanju provedenom u Quebecu u Kanadi, istaknut je porast broja djece do 10 godina koja su primljena u tamošnju hitnu stomatološku službu, unatoč besplatnoj stomatološkoj zaštiti djece koju osigurava mjesna samouprava. Kao razlozi za rijetko posjećivanje stomatologa navedeni su nedovoljna svijest roditelja o oralnom zdravlju, dugo čekanje na termin u privatnim klinikama te percepcija roditelja da stomatolog nije imao dovoljno strpljenja za rad s djetetom (7).

Slična istraživanja u drugim hitnim stomatološkim službama pokazuju da su razlozi za nastanak hitnih stanja slični rezultatima u našem istraživanju. Istraživanje provedeno 1998. godine u Klinici za maksilofacijalnu i oralnu kirurgiju Kliničke bolnice Dubrava pokazalo je u analizi hitnih stanja da je najveći broj pacijenata dolazio subotama i nedjeljama, uglavnom su bili iz dobne skupine od 16 do 31 godine, a najčešće dijagnoze bile su odontogene upale $(33,94 \%)$ i ozljede mekih tkiva (22,54\%). Od ukupno 2766 pacijenata, njih 130 (4,7\%) bilo je hospitalizirano (8). I u drugim istraživanjima uglavnom je riječ o neredovitim odlascima stomatologu - prema jednom istraživanju prosječno vrijeme trpljenja boli prije nego što se zatraži pomoć trajalo je čak dva tjedna, a u našem istraživanju to je bilo tjedan dana. Zatim, samo $46 \%$ pacijenata imalo je svojeg stomatologa, a u našem istraživanju 96,6\% ispitanika izjasnilo se da je prijavljeno preko HZZO-a (9). Razlog za neredovite odlaske stomatolo- 
ies have shown that the incidence of this disorder in adults is $5-7 \%(10,11)$, but there are studies in which much higher percentages of $6-25 \%(12,13)$ were found. Anxious patients postpone going to the dental practitioner and are inclined to seek help only when pain is acute and when the condition in the oral cavity is more serious $(14,15)$. A similar trend is the "relapse" of the same patients: $30 \%$ of them have already visited this service (9), in our survey as much as $73.1 \%$. In one study, it was shown that only $31 \%$ of patients who went to an emergency dental service visited their dentist to continue the treatment (16). Research has also shown that the main reasons for going to an emergency dental service and irregular attendance were also due to their own estimation of "no need" for regular attendance at their own registered dentist $(17,18)$. Some patients come in order to get another opinion, counsel or confirmation that their problem is not serious and that it does not endanger them, according to one research, $13 \%$ of patients (19) and in our research 5\% of them. The main reasons for the attendance of patients involved in our study were pain and swelling on the face. In our study, most of the subjects reported that the average pain in the area was 7 on the scale of 0 to 10 of where 10 indicates the greatest pain, but at the time of visiting the emergency service it was 8 . Despite experiencing severe pains, $30 \%$ of patients did not take analgesics, and it is surprising that from those who graded the current level of pain with 10, 17\% did not take analgesics, which could be explained by possible allergies to certain analgesics, using strong analgesics in permanent therapy that cannot be combined with other medication and lack of finance. On the other hand, we can take into account the fact that some patients have taken very high doses of analgesics, especially ibuprofen, which affects the subjective feeling of pain, masking pain and hindering endodontic diagnosis (20). Patients with an acute condition tend to use larger doses of analgesics than the maximally permissible doses and combine different analgesics (21).

\section{Conclusion}

In most subjects, the arrival to an emergency dental service with regard to the indication is justifiable. However, most of the conditions and the reasons for the patients' arrival are mainly due to long-term and irregular visits to the dentist, which can be attributed to the lack of awareness of the importance of oral health and dental anxiety. It would be necessary to educate patients and guide them in carrying out good oral hygiene and regular check-ups with their dental practitioners, which would probably reduce the number of emergency patients.

\section{Conflict of interest}

The authors deny any conflicts of interest. gu može biti i dentalna anksioznost. Neke su studije pokazale da je učestalost toga poremećaja kod odraslih od 5 do 7 $\%(10,11)$, no u nekim su studijama pronađeni mnogo veći razmjeri - od 6 do $25 \%(12,13)$. Anksiozni pacijenti odgađaju odlazak doktoru dentalne medicine i skloni su zatražiti pomoć tek kada je bol akutna te kada je stanje u usnoj šupljini ozbiljnije $(14,15)$. Sličan je i trend ponounih dolazaka istih pacijenata - njih $30 \%$ već je posjećivalo ovu službu (9), a u našem istraživanju čak 73,1 \%. U jednom istraživanju istaknuto je da je samo $31 \%$ pacijenata koji su došli u hitnu stomatološku službu posjetilo svojeg stomatologa radi nastavka liječenja (16). Istraživanja su također pokazala da su glavni razlozi za posjet hitnoj stomatološkoj službi te za neredoviti odlazak stomatologu nastali i zbog vlastite procjene da nema potrebe za redoviti pregled $(17,18)$. Neki pacijenti dolaze i kako bi dobili drugo mišljenje, po savjet ili po ponovnu potvrdu da njihov problem nije ozbiljan te da ih ne ugrožava - prema jednom istraživanju takvih je $13 \%$ (19), a u našem istraživanju $5 \%$.

Glavni razlozi za dolazak pacijenata uključenih u naše istraživanje bili su bolovi i otekline u području lica. $U$ našem je istraživanju većina sudionika izjavila da je prosječno najjača bol u području zbog koje dolaze bila 7 na ljestvici od 0 do 10 (na kojoj 10 označava najsnažniju bol), ali u trenutku dolaska u hitnu službu taj je broj bio 8 . Unatoč jakim bolovima analgetike nije uzelo $30 \%$ pacijenata - posebno iznenađuje da od onih koji su trenutačnu razinu boli opisali s 10, njih 17 $\%$ nije popilo analgetike. To bi se moglo objasniti alergijama na analgetike, korištenjem jakih analgetika u stalnoj terapiji koji se ne smiju kombinirati te nedostatkom novca. $S$ druge strane, u obzir možemo uzeti i činjenicu da su neki pacijenti uzimali vrlo visoke doze analgetika, posebno ibuprofena, što utječe na subjektivni osjećaj boli, maskira bol te otežava endodontsku dijagnostiku (20). Pacijenti s akutnim stanjem također su skloni uzimati veće doze analgetika od maksimalno dopuštenih te kombinirati različite analgetike (21).

\section{Zaključak}

Kod većine ispitanika postoji opravdani razlog za dolazak u hitnu stomatološku službu, $s$ obzirom na indikaciju. No većina stanja zbog kojih pacijenti dolaze nastala je uglavnom zbog neredovitih posjeta stomatologu, što možemo pripisati slaboj osviještenosti o važnosti oralnoga zdravlja, ali i dentalnoj anksioznosti. Bilo bi potrebno educirati pacijente te ih uputiti u provedbu dobre oralne higijene i istaknuti im koliko su važni redoviti odlasci na preglede kod izabranih doktora dentalne medicine, čime bi se vjerojatno smanjio broj pacijenata u hitnoj službi.

\section{Sukob interesa}

Autori nisu bili ni u kakvom sukobu interesa. 
Sažetak

Svrha: Svrha rada bila je odrediti socijalno-demografske i kliničke parametre pacijenata koji posjećuju hitnu stomatološku službu te njihove najčešće dijagnoze. Materijali i metode: Podatci su prikupljeni na temelju ankete koju su pacijenti ispunjavali za posjeta službi. Ukupno je sudjelovalo 1730 pacijenata (26\%) od njih 6732, s pritom se ispunjavala anketa u kojoj su postavljena pitanja o socijalno-demografskom statusu i posjećivanju stomatologa te je tražen opis i dinamika simptoma. Nakon prikupljanja podataka provedene su metode deskriptivnog prikaza podataka te metode inferencijalne statistike u SPSS-u. Rezultati: Rezultati nakon analize ankete pokazali su da većina ispitanika $(60,4 \%)$ dolazi u hitnu službu vikendima i blagdanima. Istaknimo da je $73,1 \%$ ispitanika naveo je da se već koristio uslugama hitne stomatološke službe, a $65,8 \%$ njih zbog trenutačnog stanja nije posjetilo svojega stomatologa. Najveći broj ispitanika (62,2 \%) u hitnu je službu došao unutar tjedan dana od početka tegoba. Najčešće dijagnoze bile su apscesi lica i čeljusti (27,3\%). Postoji statistički značajna razlika između broja pacijenata koji su došli u hitnu stomatološku službu i ispunili upitnik tijekom različitih mjeseci, u smislu da je više njih tražilo pomoć tijekom svibnja i lipnja $(59,7 \%$ ) u odnosu prema srpnju i kolovozu (40,3 \%). Zaključak: Kod većine ispitanika postojale su jasne indikacije za prijam u hitnu stomatološku službu. Većina hitnih stanja nastala je uglavnom zbog neredovitih posjeta izabranom liječniku. Boljom edukacijom pacijenata i provedbom preventivnih programa broj posjeta ovoj službi vjerojatno bi se smanjio.
Zaprimljen: 26. veljače 2019. Prihvaćen: 25. srpnja 2019.

Adresa za dopisivanje Alem Fazlić, dr.med.dent. Dom zdravlja Zagreb - Centar Runjaninova 4, 10000 Zagreb, Hrvatska alem.fazlic@gmail.com

Ključne riječi

dentalna anksioznost; akutna bol; hitna medicina

\section{References}

1. Klaić B, Bartolić V, Šostar Z, Baučić I. Organizacija hitne stomatološke službe grada Zagreba i Zagrebačke županije. Acta stomatol Croat. 2003;37(3):12-23.

2. Pegon-Machat E, Faulks D, Eaton KA, Widström E, Hugues P, Tubert-Jeannin S. The healthcare system and the provision of oral healthcare in EU Member States: France. Br Dent J. 2016 Feb 26;220(4):197-203.

3. Bravo M, San Martín L, Casals E, Eaton KA, Widström E. The healthcare system and the provision of oral healthcare in European Union member states. Part 2: Spain. Br Dent J. 2015 Dec;219(11):547-51.

4. Sayers M, Rowland H, Djemal S. Experiences in a dental emergency clinic. Eur J Prosthodont Restor Dent. 2004 Mar;12(1):5-8.

5. Alnaggar D, Andersson L. Emergency management of traumatic dental injuries in 42 countries. Dent Traumatol. 2015 Apr;31(2):89-96.

6. Matsumoto MS, Gatti MA, de Conti MH, de Ap Simeão SF, de Oliveira Braga Franzolin S, Marta SN. Determinants of Demand in the Public Dental Emergency Service. J Contemp Dent Pract. 2017 Feb 1;18(2):156-161.

7. Mostajer Haqiqi A, Bedos C, Macdonald ME. The emergency department as a 'last resort': why parents seek care for their child's nontraumatic dental problems in the emergency room. Community Dent Oral Epidemiol. 2016 Oct;44(5):493-503.

8. Brajkovic B, Macan D. Raščlamba hitnih slučajeva u Klinici za kirurgiju lica, čeljusti i usta KB “Dubrava”. Acta Stomat Croat. 2002;36(2):213-217.

9. Currie CC, Stone SJ, Durham J. Pain and problems: a prospective cross-sectional study of the impact of dental emergencies. J Oral Rehabil. 2015 Dec;42(12):883

10. Crego A, Carrillo-Díaz M, Armfield JM, Romero M. From Public Mental Health to Community Oral Health: The Impact of Dental Anxiety and Fear on Dental Status. Front Public Health. 2014 Feb 28;2:16.
11. Hakeberg M, Berggren U, Carlsson SG. Prevalence of dental anxiety in an adult population in a major urban area in Sweden. Community Dent Oral Epidemiol. 1992 Apr;20(2):97-101.

12. Schuller AA, Willumsen T, Holst D. Are there differences in oral health and oral health behavior between individuals with high and low dental fear? Community Dent Oral Epidemiol. 2003 Apr;31(2):116-21.

13. Oosterink FM, de Jongh A, Hoogstraten J. Prevalence of dental fear and phobia relative to other fear and phobia subtypes. Eur J Oral Sci. 2009 Apr; 117(2):135-43.

14. Perkovic I, Peric M, Romic Knezevic M, Jukić Krmek S. Razina anksioznosti i percepcija bola endodontskih pacijenata. Acta stomatol Croat. 2014;48(4):258-267

15. Serra-Negra J, Paiva SM, Oliveira M, Ferreira E, Freire-Maia E, Pordeus I. Self-Reported Dental Fear among Dental Students and Their Patients. Int J Environ Res Public Health. 2012 Jan;9(1):4445

16. Beau Meyer, Eric Adkins, Nathan M Finnerty, Fonda G Robinson Determining the rate of follow-up after hospital emergency department visits for dental conditions. Clin Cosmet Investig Dent. 2016 Mar 30;8:51-6.

17. Hill K B, Chadwick B, Freeman R, O’Sullivan I, Murray J J. Adult dental health survey 2009: Relationships between dental attendance patterns, oral health behaviour and the current barriers to dental care. Br Dent J. 2013 Jan;214(1):25-32.

18. Nayee S, Kutty S, Akintola D. Patient attendance at a UK dental hospital emergency clinic. Br Dent J. 2015 Nov 27;219(10):485-8.

19. Anderson R. Patient expectations of emergency dental services: qualitative interview study. Br Dent J. 2004 Sep 25;197(6):331-4.

20. Read JK, McClanahan SB, Khan AA, Lunos S, Bowles WR. Effect of Ibuprofen on masking endodontic diagnosis. J Endod. 2014 Aug;40(8):1058-62.

21. Hommez G, Ongena B, Cauwels RGEC, De Paepe P, Christiaens V, Jacquet W. Analgesia (mis) usage on a dental emergency service: a patient survey. Clin Oral Investig. 2018 Apr;22(3):1297-1302. 